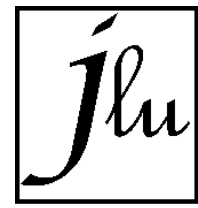

https://jurnal.univpgri-

palembang.ac.id/index.php/luminous
Jurnal Luminous 02 (2) (2021) 11-17

Riset IImiah Pendidikan Fisika

Vol. 2 No. 2 (2021) hal 11-17
E-ISSN 2715-6990

P-ISSN 2715-9582

$\mathrm{mm} 20 \mathrm{XX}$

\title{
PENGEMBANGAN LEMBAR KEGIATAN PESERTA DIDIK BERBASIS MULTIMODUS REPRESENTASI PADA KONSEP MOMENTUM DAN IMPULS UNTUK MELATIHKAN KETERAMPILAN PROSES SAINS
}

\author{
Masrifah $^{{ }^{*}}$, Nasrun Balulu ${ }^{1}$, Haryanti Nengkeula ${ }^{1}$ \\ ${ }^{1}$ Program studi Pendidikan Fisika, Fakultas Keguruan dan IImu Pendidikan, Universitas Khairun Ternate \\ Jalan Bandara Baabullah Kota Ternate, 97728, Indonesia \\ E-mail: masrifah@unkhair.ac.id
}

Received: 3107 2021. Accepted: 3107 2021. Published: 082021

\begin{abstract}
Abstrak
Penelitian ini bertujuan untuk mengembangkan Lembar Kerja Peserta Didik (LKPD) berbasis multimodus representasi pada konsep momentum dan impuls untuk melatihkan keterampilan proses sains yang valid. Penelitian ini merupakan penelitian pengembangan Research \& Development (R\&D) menurut Borg and Gall yang dibatasi sampai dengan tahap kelima, yakni revisi produk. Instrumen yang digunakan dalam penelitian pengembangan LKPD ini berupa instrumen validasi LKPD yang divalidasi oleh beberapa ahli di bidang Fisika, yakni 3 orang dosen program studi Fisika dan 2 guru SMA. Data hasil validasi yang diperoleh kemudian dianalisis menggunakan persentase. Berdasarkan hasil analisis data diperoleh rata-rata persentase untuk komponen isi sebesar $3,47 \%$, komponen tampilan sebesar $3,45 \%$ dan komponen bahasa sebesar 3,72\%. Sedangkan rata-rata persentase total komponen sebesar $3,55 \%$ dan berada pada kategori sangat valid. Dengan demikian dapat disimpulkan bahwa LKPD berbasis multimodus representasi yang dikembangkan untuk melatihkan keterampilan proses sains pada konsep momentum dan impuls layak digunakan dalam proses pembelajaran untuk siswa SMA kelas $\mathrm{X}$.
\end{abstract}

Kata Kunci: LKPD, multimodus representasi, KPS.

\section{PENDAHULUAN}

Fisika adalah salah satu ilmu dasar yang memegang peranan penting dalam perkembangan ilmu pengetahuan dan teknologi. Namun kenyataan di lapangan masih banyak siswa yang menganggap Fisika merupakan salah satu mata pelajaran yang sulit dan tidak digemari sehingga siswa kurang termotivasi dalam belajar fisika. Sebagian besar siswa hanya cenderung menghafal rumus-rumus saja tanpa memahami konsep fisika itu sendiri. Bahkan siswa tidak mengetahui manfaat konsep fisika atau aplikasinya pada kehidupan sehari-hari. Hal itu dapat mempengaruhi pemahaman konsep siswa. Untuk itu, guru harus dapat merubah mindset siswa tersebut. Guru harus mampu menciptakan pembelajaran fisika yang menyenangkan dan bermakna. 
Dalam kurikulum 2013 kegiatan pembelajaran diarahkan untuk memberdayakan semua potensi yang dimiliki peserta didik agar mereka dapat memiliki kompetensi yang diharapkan melalui upaya menumbuhkan serta mengembangkan sikap, pengetahuan, dan keterampilan (Deden, 2015).

Salah satu upaya untuk mengembangkan potensi peserta didik dalam proses pembelajaran yakni, melalui penggunaan Lembar Kegiatan Peserta Didik (LKPD). LKPD merupakan aktivitas peserta didik dalam pembelajaran untuk menerapkan atau mempraktekkan ilmu yang telah diperoleh. LKPD tersebut sangat penting untuk mengetahui keberhasilan peserta didik dalam menyerap dan menguasai ilmu yang telah diberikan (Widodo, 2017).

Melalui kegiatan dalam LKPD tersebut, guru dapat mengamati peserta didik yang telah memahami materi yang diberikan dan yang belum memahaminya. LKPD dibuat dengan tujuan untuk membantu peserta didik menemukan suatu konsep baik melalui praktikum maupun teori dan membantu peserta didik menerapkan dan mengintegrasikan berbagai konsep yang telah ditemukan.

Namun LKPD yang digunakan di sekolah saat ini tidak melatih peserta didik untuk melakukan proses penyelidikan karena hanya berisi kumpulan soal yang harus dikerjakan (Permatasari, 2018). Hasil observasi pada beberapa guru di sekolah SMA/MA kelas X Maluku Utara diperoleh informasi bahwa sebagian besar guru sudah menggunakan LKPD dalam proses pembelajaran fisika. Sebagian guru menyusun LKPD sendiri dan yang lainnya menggunakan LKPD yang beredar dari penerbit. Menurut guru, LKPD yang digunakan masih memiliki kekurangan yaitu sebagian isi LKPD belum memenuhi kriteria pemahaman yang diuji. LKPD kurang mengembangkan Keterampilan Proses Sains (KPS) peserta didik. Selain itu, ilustrasi, gambar dan isinya kurang menarik.

Tujuan dalam penelitian ini adalah untuk mengembangkan LKPD berbasis multimodus representasi untuk melatihkan KPS peserta didik pada konsep impuls momentum yang layak digunakan dalam proses pembelajaran.

\section{METODE}

Penelitian ini merupakan penelitian pengembangan atau Research \& Development $(R \& D)$ yang menghasilkan produk LKPD berbasis multimodus representasi untuk melatihkan KPS peserta didik. Peneliti memilih menggunakan metode penelitian Educational Research and Development (R\&D) karena metode ini menekankan pada pengembangan produk-produk yang efektif digunakan dalam kegiatan pendidikan. Model pengembangan yang digunakan adalah menurut Borg and Gall (2003). Dimana penelitian ini mengikuti langkah-langkah yang telah ditentukan untuk mengembangkan suatu produk baru atau menyempurnakan produk yang sudah ada, kemudian dievaluasi sehingga diperoleh kriteria tertentu yang lebih efektif. Penelitian ini dibatasi hanya sampai pada tahap kelima, yakni revisi produk.

Instrumen yang digunakan dalam penelitian pengembangan LKPD ini berupa instrumen validasi LKPD yang meliputi komponen isi, tampilan, dan bahasa. Instrumen tersebut digunakan untuk melihat kevalidan LKPD yang dihasilkan. Instrumen tersebut divaliditasi dan diuji reliabilitasnya terlebih dahulu sebelum digunakan. Produk LKPD divalidasi oleh beberapa ahli di bidang Fisika, yakni 3 orang dosen program studi Fisika dan 2 guru SMA. Data hasil validasi ahli yang diperoleh kemudian dianalisis secara deskriptif menggunakan persentase. Selanjutnya validitas tiap komponen penilaian LKPD ditentukan dengan mengacu pada kriteria yang terdapat pada Tabel 1.

Tabel 1. Kriteria penilaian validasi LKPD Dimodifikasi dari: Ratumanan dan Laurens (2011).

\begin{tabular}{|c|c|c|}
\hline $\begin{array}{l}\text { Interval Skor Hasil } \\
\text { Penilaian }\end{array}$ & $\begin{array}{c}\text { Kategor } \\
\text { i }\end{array}$ & Keterangan \\
\hline $3,25<$ Skor $\leq 4,00$ & $\begin{array}{l}\text { Sangat } \\
\text { valid }\end{array}$ & $\begin{array}{l}\text { Dapat digunakan tanpa } \\
\text { revisi }\end{array}$ \\
\hline $2,50<$ Skor $\leq 3,22$ & Valid & $\begin{array}{l}\text { Dapat digunakan } \\
\text { dengan sedikit revisi }\end{array}$ \\
\hline
\end{tabular}




\begin{tabular}{lll}
$1,75<$ Skor $\leq 2,50$ & Kurang & $\begin{array}{l}\text { Dapat digunakan } \\
\text { valid }\end{array}$ \\
$\begin{array}{l}\text { dengan banyak revisi } \\
\text { Tidak }\end{array}$ & $\begin{array}{l}\text { Belum dapat digunakan } \\
\text { valid }\end{array}$ & $\begin{array}{l}\text { dan masih memerlukan } \\
\text { konsultasi }\end{array}$ \\
\hline
\end{tabular}

Sementara masukan dan saran dari para ahli akan digunakan sebagai bahan dalam penyempurnaan LKPD yang telah dikembangkan.

\section{HASIL DAN PEMBAHASAN}

Berdasarkan hasil studi lapangan melalui penyebaran angket pada guru Fisika SMA di Maluku Utara diperoleh informasi bahwa LKPD yang digunakan dalam pembelajaran fisika yaitu LKPD yang beredar dari berbagai penerbit dan LKPD yang digunakan masih memiliki kekurangan, yakni sebagian isi LKPD belum memenuhi kriteria pemahaman yang diuji, gambar serta isinya kurang menarik. LKPD yang digunakan di sekolah juga masih bersifat cookbook dimana langkahlangkah kegiatan praktikum sudah ditentukan semua dan peserta didik harus mengikutinya. Hal itu kurang memfasilitasi pengembangan potensi dan kreativitas siswa serta kurang menuntut pemahaman konsep siswa.

Berdasarkan temuan dari hasil studi lapangan tersebut, Peneliti berupaya memberikan solusi dengan mengembangkan LKPD yang disajikan dalam bentuk multirepresentasi atau berbagai bentuk representasi seperti teks, gambar, diagram piktorial, grafik, tabel, dan persamaan matematis sehingga lebih mudah dipahami oleh peserta didik. LKPD juga dikembangkan berdasarkan indikator-indikator KPSkarena LKPD yang selamaini digunakan di sekolah kurang dalam melatihkan KPS pada peserta didik. Desain LKPD Fisika SMA/MA berbasis multimodus representasi untuk melatihkan KPS yang dikembangkan dalam penelitian ini dideskripsikan sebagai berikut:

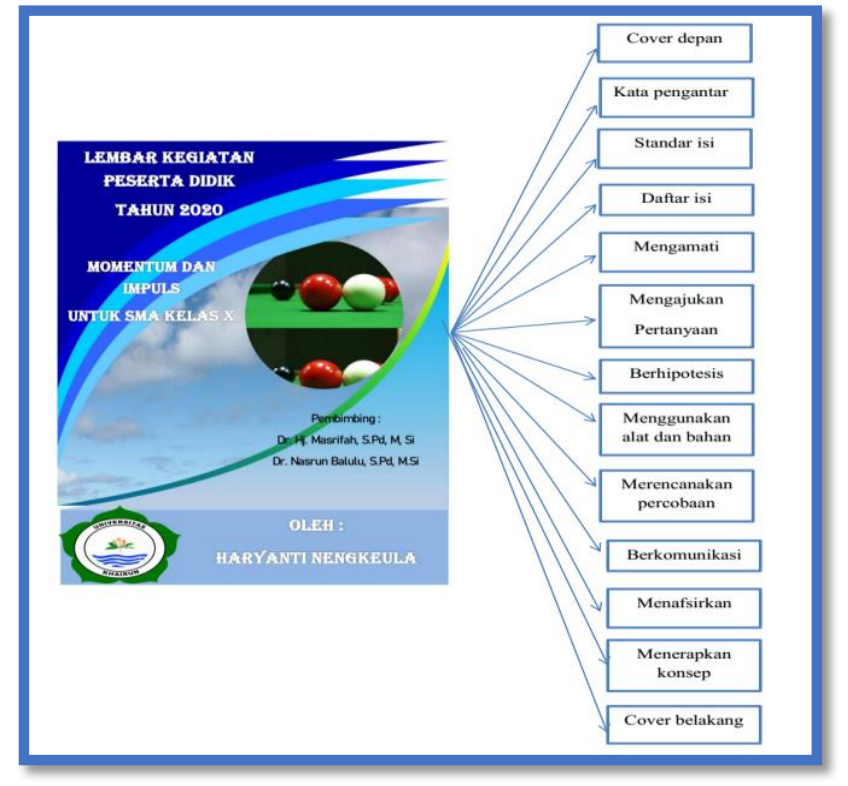

Gambar 1. Skema LKPD berbasis multimodus representasi

Hasil penelitian ini akan diuraikan berdasarkan proses pengembangan LKPD berbasis multimodus representasi dengan tahapan berikut: (1) Tahap pendahuluan; (2) Perencanaan; (3) pengembangan; (4) Validasi produk; (5) Revisi produk. Tujuannya adalah untuk mengetahui alur perkembangan produk dari tahap awal sampai tahap akhir.

Pada tahap pendahuluan, Peneliti mengumpulkan informasi awal terkait permasalahan yang dikaji melalui studi literatur dan studi lapangan. Studi literature melalui analisis kurikulum, perangkat pembelajaran, dan hasil riset yang relevan. Sedangkan studi lapangan dilakukan dengan cara menganalisis kebutuhan di lapangan melaluiangket yang disebar pada guru fisika SMA/MA terkait permasalahan yang dikaji.

Berdasarkan hasil analisis pada tahap pendahuluan tersebut selanjutnya dilakukan tahap perencanaan untuk merancang produk yang dikembangkan. Pada tahap perencanaan ini dirancang tujuan pengembangan LKPD, materi atau konsep fisika yang akan dikembangkan, dan instrumen yang akan digunakan. Tujuan pengembangan LKPD adalah untuk melatihkan KPS peserta didik pada konsep momentum dan impuls. Sementara instrumen yang dirancang yakni lembar validasi ahli untuk melihat kevalidan 
LKPD yang dikembangkan. Hasil uji reliabilitas alpha Cronbach's terhadap instrumen dengan bantuan software IBM SPSS.20 menunjukkan bahwa reliabiliatasnya berada pada kategori tinggi, yakni sebesar 0,961 .

Pada tahap pengembangan, Peneliti menggunakan pendekatan multimodus representasi untuk menyajikan konten LKPD. Melalui pendekatan ini, konten disajikan dalam berbagai bentuk representasi, yakni teks, gambar, diagram piktorial, tabel, grafik, dan persamaan matematis untuk mempermudah peserta didik dalam memahami konsep. LKPD juga dikembangkan berdasarkan indikator keterampilan proses sains sesuai dengan tujuan pengembangan LKPD yang telah dirumuskan.

Selanjutnya pada tahap validasi produk, Peneliti melakukan uji validitasi pada 5 orang ahli di bidang fisika untuk mengetahui bagaimana kevalidan LKPD yang dikembangkan. Validitas LKPD menjadi hal yang sangat penting untuk diperhatikan dalam penelitian pengembangan LKPD. Instrumen validasi isi LKPD meliputi beberapa komponen, yakni (1) komponen isi, (2) komponen tampilan, dan (3) komponen bahasa. Instrumen terdiri-dari indikator penilaian, skala skor, dan kolom saran.

Hasil dari validasi tiap ahli LKPD berbasis multimodus representasi pada konsep momentum dan impuls untuk melatihkan keterampilan proses sains siswa SMA pada rata-rata komponen isi, tampilan dan bahasa dapat dilihat pada diagram batang berikut:

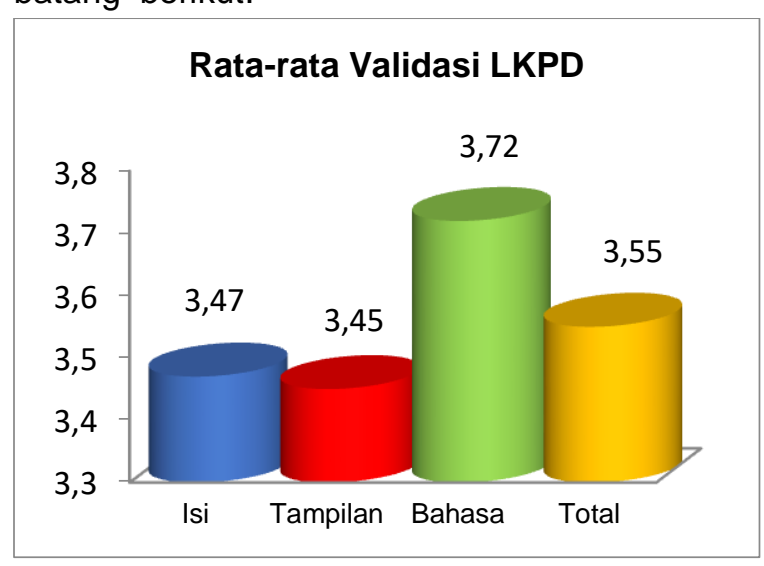

Gambar 2. Diagram data hasil validasi ahli
Berdasarkan hasil penilaian dari validator yang disajikan pada Gambar 1, terlihat bahwa LKPD berbasis multimodus representasi untuk melatihkan KPS yang dikembangkan sangat valid dilihat dari aspek komponen isi, tampilan, dan bahasa dengan perolehan rata-rata total komponen adalah 3,55. Sehingga, dari data tersebut secara keseluruhan dapat dikatakan bahwa LKPD berbasis multimodus representasi untuk melatihkan KPS yang dikembangkan layak digunakan dalam proses pembelajaran. Validitas ini juga memperjelas bahwa LKPD pada konsep momentum dan impuls yang dikembangkan telah sesuai dengan Kompetensi Inti (KI) dan Kompetensi Dasar (KD) yang digunakan untuk konsep momentum dan impuls mengacu pada kurikulum 2013.

Temuan hasil penelitian memperlihatkan bahwa komponen bahasa memiliki nilai validitas yang paling besar. Hal itu menunjukkan bahwa LKPD yang dirancang dapat terbaca dengan baik, memiliki informasi yang jelas dan tidak menimbulkan kerancuan bagi peserta didik karena disusun dengan menggunakan kaidah Bahasa Indonesia yang baik dan benar. Hasil validasi pada aspek kebahasaaan telah sesuai dengan pendapat Depdiknas (2008) yang menyatakan bahwa informasi di dalam LKPD seharusnya menggunakan bahasa yang baik, agar peserta didik dapat mengembangkan pengetahuan dan wawasan peserta didik.

Pada komponen isi LKPD berada pada kategori sangat valid karena konten LKPD disajikan dengan menggunakan pendekatan multimodus representasi. Dimana melalui multirepresentasi, konsep yang sama dapat dijelaskan dengan berbagai jenis modus representasi (Ainsworth, 1999). Tampilan berbagai representasi dalam penanaman suatu konsep diprediksi akan dapat lebih membantu peserta didik dapat memahami konsep yang dipelajari. Pendekatan multirepresentasi berperan membantu pebelajar dalam mengembangkan sebuah pemahaman yang lebih baik karena suatu konsep yang dipaparkan dengan menggunakan pendekatan multirepresentasi dapat meningkatkan 
pemahaman yang mendalam. Sehingga pebelajar dapat membangun pemahaman yang utuh pada konsep terkait (Masrifah dkk, 2020).

Multirepresentasi dapat dijadikan sebagai pendekatan dalam pembelajaran Fisika mengingat setiap peserta didik memiliki kemampuan sfesifik yang lebih menonjol dibanding kemampuan lainnya. Ada peserta didik yang lebih menonjol kemampuan verbalnya dibanding kemampuan spasial dan kuantitatifnya, tetapi ada juga yang sebaliknya. Jika sajian konsep hanya ditekankan pada satu representasi saja, maka akan menguntungkan sebagian peserta didik dan tidak menguntungkan bagi yang lainnya. Misalnya sajian konsep hanya dinyatakan dalam representasi verbal, maka peserta didik yang lebih menonjol kemampuan spasialnya akan sulit memahami konsep yang disajikan.

LKPD dikembangkan untuk melatihkan ketermapilan proses sains peserta didik karena pembelajaran fisika tidak lepas dari proses penyelidikan ilmiah yang sistematis. Keterampilan proses sains adalah keterampilan prosedural, eksperimental, dan sistemik sains sebagai dasar sains. Oleh karena itu penting bagi guru dan siswa untuk memiliki pemahaman yang baik tentang keterampilan proses sains (Limatahu dan Rahman, 2020). Keterampilan proses sains, baik keterampilan proses sains dasar maupun keterampilan proses sains terintegrasi harus dilatihkan kepada peserta didik agar peserta didik tidak hanya menjadi penerima informasi, tetapi juga dapat melakukan pencarian informasi terkait dengan hal-hal yang dipelajari.

Pada tahap revisi, Peneliti melakukan perbaikan berdasarkan saran dan masukan dari validator ahli pada tahap validasi produk. Meskipun secara keseluruhan, hasil uji validitas oleh lima validator menyatakan bahwa LKPD Fisika yang dikembangkan validitasnya sudah sangat valid, namun demikian masih perlu dilakukan perbaikan untuk lebih menyempurnakan LKPD tersebut.

\section{SIMPULAN}

Berdasarkan hasil penelitian dapat disimpulkan bahwa LKPD momentum dan impuls berbasis multimodus representasi untukmelatihkan keterampilan proses sains yang dikembangkan sangat valid dengan rata-rata total komponen validitas sebesar 3,55. Pada komponen isi diperoleh nilai rata-rata 3,47 , komponen tampilan sebesar 3,45 dan kompoen bahasa sebesar 3,72. Dengan demikian LKPD berbasis multimodus representasi pada konsep momentum dan impuls untuk melatihkan keterampilan proses sains yang dikembangkan dapat digunakan dalam ujicoba secara luas dalam proses pembelajaran untuk siswa SMA kelas $\mathrm{X}$.

\section{DAFTAR PUSTAKA}

Deden. (2015). Penerapan pendekatan saintifik dengan menggunakan model pembelajaran inkuiri

pada mata pelajaran ekonomi. Diakses pad a tanggal 05 April 2018 dari https://www.goo gle.co.id/url?sa=t\&rct=i\&q=\&esrc=s\&source $=$ web \&cd $=1 \& c a d=$ rja\&uact $=8 \&$ ved $=2$ ahUKE wilvdS288XhAhXVFogKHT1UDS4QFjAAeg QIABAC\&url=http\%3A\%2F\%2Feprints.uny. ac.id\%2F21691\%2F1\%2F11\%2520Deden.p df\&usg=AOvVaw3pcy06VijhLUW7B rrerNE

Widodo Slamet. (2017). Pengembangan Lembar Kegiatan Peserta Didik (LKPD) berbasis Pendekatan Saintifik untuk Meningkatkan Keterampilan Penyelesaian Masalah Lingkungan Sekitar. JPIS, 26(2), 189-204.

Permatasari Bella. (2018). Pengembangan LKPD Berbasis $P O E$ untuk pembelajaran fisika materi momentum dan impuls SMA.

Borg \& Gall, (2003) Education Research: An Introduction. Eighth Edition. Boston, USA: Person Education, inc.

Ratumanan, G.T dan Laurens, T. (2011). Penilaian Hasil Belajar Tingkat Satuan Pendidikan. Surabaya: Unesa University Press. 
Ainsworth, S. (1999). The functions of multiple representations. Computer and Education Journal. 33, 131-152.

Masrifah, Setiawan A, Sinaga P, dan Setiawan W. (2020). An Investigation of Physics Teachers' Multiple Representation Ability on Newton's Law Concept. JPPPF (Jurnal Penelitian dan Pengembangan Pendidikan Fisika). 6(1), 105-111.

Limatahu I dan Rahman R. (2020). Melatihkan Keterampilan Proses Sains siswa SMA Negeri 8 Kota Ternarte melalui penerapan model pembelajaran CCDSR (Condition, Construction, Development, Simulation, Reflection). JPPS (Jurnal Penelitian Pendidikan Sains). 9(2). 